\title{
Antifungal Activity of Silver Ions and Nanoparticles on Phytopathogenic Fungi
}

Young-Ki Jo, Department of Plant Pathology and Microbiology, Texas A\&M University, College Station, TX 77843; and Byung H. Kim, Department of Mechanical and Industrial Engineering, and Geunhwa Jung, Department of Plant, Soil \& Insect Sciences, University of Massachusetts, Amherst, MA 01003

\begin{abstract}
Jo, Y.-K., Kim, B. H., and Jung, G. 2009. Antifungal activity of silver ions and nanoparticles on phytopathogenic fungi. Plant Dis. 93:1037-1043.

Silver in ionic or nanoparticle forms has a high antimicrobial activity and is therefore widely used for various sterilization purposes including materials of medical devices and water sanitization. There have been relatively few studies on the applicability of silver to control plant diseases. Various forms of silver ions and nanoparticles were tested in the current study to examine the antifungal activity on two plant-pathogenic fungi, Bipolaris sorokiniana and Magnaporthe grisea. In vitro petri dish assays indicated that silver ions and nanoparticles had a significant effect on the colony formation of these two pathogens. Effective concentrations of the silver compounds inhibiting colony formation by $50 \%\left(\mathrm{EC}_{50}\right)$ were higher for $B$. sorokiniana than for $M$. grisea. The inhibitory effect on colony formation significantly diminished after silver cations were neutralized with chloride ions. Growth chamber inoculation assays further confirmed that both ionic and nanoparticle silver significantly reduced these two fungal diseases on perennial ryegrass (Lolium perenne). Particularly, silver ions and nanoparticles effectively reduced disease severity with an application at $3 \mathrm{~h}$ before spore inoculation, but their efficacy significantly diminished when applied at $24 \mathrm{~h}$ after inoculation. The in vitro and in planta evaluations of silver indicated that both silver ions and nanoparticles influence colony formation of spores and disease progress of plant-pathogenic fungi. In planta efficacy of silver ions and nanoparticles is much greater with preventative application, which may promote the direct contact of silver with spores and germ tubes, and inhibit their viability.
\end{abstract}

Silver is a prehistoric element. Even ancient Babylonians and Greeks possessed many silver mines (23). However, the use of silver for medicine or local antibacterial agents was not recognized until the nineteenth century $(9,19,28)$. Since then, the antimicrobial property of silver has been investigated and employed more extensively than any other inorganic antibacterial agent (24). Silver is known to attack a broad range of biological processes in microorganisms including the alteration of cell membrane structure and functions $(16,20,26)$. Silver also inhibits the expression of proteins associated with ATP production (30), although its specific antimicrobial mechanisms are still not completely understood.

Micromolar doses ( 1 to $10 \mu \mathrm{M}$ ) of silver ions are sufficient to kill bacteria in water (14), while silver can be toxic at high doses to mammals $(5,8)$ and freshwater and marine organisms $(3,17)$, probably compromising the growth and shape of

Corresponding author: Geunhwa Jung

E-mail: jung@psis.umass.edu

* The $\boldsymbol{e}$-Xtra logo stands for "electronic extra" and indicates that Figures 1 and 4 appear in color in the online edition.

Accepted for publication 22 June 2009.

doi:10.1094/PDIS-93-10-1037

(C) 2009 The American Phytopathological Society animal cells by disrupting a variety of biological functions (5). Such micromolar concentrations of silver have no harmful effects on humans (2). Therefore, silver has been widely used for the development of many biological and pharmaceutical processes, products, and appliances such as coating materials for medical devices (22), orthopedic or dental graft materials $(10,15)$, topical aids for wound repair $(6)$, water sanitization $(9,13,14)$, textile products (27), and even washing machines (12).

The use of nano-sized silver particles as antimicrobial agents has become more common as technological advances make their production more economical. One of the potential applications in which silver can be utilized is in management of plant diseases. Since silver displays multiple modes of inhibitory action to microorganisms (4), it may be used for controlling various plant pathogens in a relatively safer way compared to synthetic fungicides (21). Until now, limited research provided some evidence of the applicability of silver for controlling plant diseases (21). Primary requirements for the potential use of silver in plant disease control include more information about antifungal activity of various silver compounds to plant pathogens and the development of better application strategies to increase the efficacy of disease suppression. The objectives of this study were to determine the inhibitory property of silver ions and nanoparticles on colony formation of plant-pathogenic fungi, and to evaluate the efficacy of the silver compounds for disease control on plants.

\section{MATERIALS AND METHODS}

Fungal isolates. Two conidia-producing fungi that are economically important pathogens of grasses were used in the study: Bipolaris sorokiniana (Sacc.) Shoem, which causes seedling blight, root rot, crown rot, and leaf spot blotch on various gramineous species, and Magnaporthe grisea (Hebert) Barr, which causes blast on rice (Oryza sativa L.) and gray leaf spot on turfgrass. A single-spore isolate of each fungus was used to avoid possible compound effects caused by using a mixture of genetically different isolates. A single-spore isolate (LS-WI06) of $B$. sorokiniana was collected from infected plants of perennial ryegrass (Lolium perenne L.) in Verona, WI in 2006. One lab isolate (6082) of $M$. grisea, which was capable of pathogenicity on both rice and perennial ryegrass, was provided by $\mathrm{S}$. Leong at the University of Wisconsin. For long-term storage, these isolates were stored as frozen conidia on filter paper at $-20^{\circ} \mathrm{C}$.

Silver preparation. The silver preparations used in this study were $\mathrm{AgNO}_{3}$, $\mathrm{AgCl}$, nanoparticle $\mathrm{Ag} \mathrm{(20} \mathrm{to} 30 \mathrm{~nm}$ in diameter; Quantum Sphere Inc., Santa Ana, CA [indicated as $\mathrm{Ag}(\mathrm{p})$ ]), and electrochemical Ag (indicated as $\mathrm{Ag}(\mathrm{e})$ ). For preparing $\mathrm{AgCl}$ and $\mathrm{Ag}(\mathrm{p}), \mathrm{AgCl}$ salt or $\mathrm{Ag}(\mathrm{p})$ powder was weighed and suspended in sterile, deionized water using a sonicator (Bransonic, Branson Ultrasonic Corporation, Danbury, CT). $\operatorname{Ag}(\mathrm{e})$ solution was generated by electrolysis at $30 \mathrm{~V}$ with two silver electrodes $(10 \mathrm{~cm}$ long, $2 \mathrm{~mm}$ diameter, and $3 \mathrm{~cm}$ between electrodes) in $500 \mathrm{ml}$ of distilled water as previously described by Simonetti et al. (25). Silver ion concentrations of each silver preparation were measured at room temperature using an ion meter equipped with a silver ion-selective electrode (Weiss Research Inc., Houston, TX). Particularly, to further examine the antifungal effect of silver ions, each silver preparation was titrated with $\mathrm{NaCl}(500 \mathrm{mM})$ until silver ions were removed and undetected by the ion meter. To prepare different silver concentrations, subsamples of each silver preparation were diluted with sterile, deionized water. The range of silver concentrations used to test the sensitivity of each pathogen to each 
silver preparation was determined based on our preliminary trials and is listed in Table 1.

Inhibition of colony formation by silver. The antifungal activity of silver ions and nanoparticles was examined on the basis of colony formation by in vitro petri dish assays. Each fungal isolate was cultured on growth media that induced prolific conidia production. The B. sorokiniana isolate (LS-WI06) was grown on V8 agar medium, and the $M$. grisea isolate (6082) was grown on oatmeal agar medium. Conidia were collected from cultures that were incubated at $25^{\circ} \mathrm{C}$ for 10 days and diluted with sterile, deionized water to a concentration of $10^{6}$ spores $\mathrm{ml}^{-1}$. Aliquots of the conidial suspension were mixed with serial concentrations of silver preparations to a final volume of $1 \mathrm{ml}$ (Table 1), and were also mixed with sterile, deionized water as water controls.

A 10- $\mu$ l subsample of the conidia and silver mixture stock was taken at $0,1,3$, and $6 \mathrm{~h}$ after silver treatments and diluted 100 -fold with sterile, deionized water. A $10-\mu$ aliquot of the diluted spore suspension was spread on potato dextrose agar (PDA; Becton, Dickson and Company, Sparks, MD) medium. PDA was used because it was easier to examine colony formation than on V8 or oatmeal medium. Three PDA plates per each combination of exposure time and silver concentration were tested. The number of colonies forming on plates was counted after 2 and 4 days at $25^{\circ} \mathrm{C}$ for $B$. sorokiniana and $M$. grisea, respectively. The average number of colonies from silver-treated spore suspensions was compared with the number on the water control (percent colony formation) in order to calculate the concentration of each silver preparation that caused a $50 \%$ reduction in colony formation $\left(\mathrm{EC}_{50}\right)$. This experiment was conducted twice. For each treatment combination of exposure time and silver concentration, a linear regression of the percent colony formation versus the log-transformed silver concentration was obtained to calculate the $\mathrm{EC}_{50}$ value.

In planta efficacy of silver. The efficacy of silver ions and nanoparticles in reducing diseases on plants was examined with in planta inoculation experiments conducted in a growth chamber. Perennial ryegrass was seeded on $25 \mathrm{~cm}^{2}$ pots filled with potting mix (Metro-Mix, Sun Gro, Bellevue, WA), and 20 to 25 plants were grown per plot for 1 month before use in the experiment. These pots were arranged at random with four replicates per treatment. Silver compounds were diluted to two different concentrations with sterile, deionized water (Table 2) and mixed with $0.2 \%$ surfactant (Spreader Sticker, Gardens Alive Inc., Lawrenceburg, IN) before application.

To examine whether application timing would affect the efficacy of silver, the silver preparations were applied at two times: $3 \mathrm{~h}$ before or $24 \mathrm{~h}$ after conidia inoculation. For preinoculation treatments, silver preparations were sprayed on perennial ryegrass plants with an aspirator (Badger 350, Badger Air-Brush Co., Franklin Park, IL) and allowed to air-dry at room temperature for $3 \mathrm{~h}$ followed by inoculation with conidial suspensions $\left(10^{5}\right.$ conidia $\mathrm{ml}^{-1}+0.2 \%$ Tween 20 ) of B. sorokiniana or $M$. grisea. The inoculated plants were incubated in a plastic container with lid (Sterilite, Townsend, MA; $76 \mathrm{~cm} \mathrm{~L}$ $\times 45 \mathrm{~cm} \mathrm{~W} \times 33 \mathrm{~cm} \mathrm{H}$ ) for $24 \mathrm{~h}$ at $25^{\circ} \mathrm{C}$ and $100 \%$ relative humidity, and then transferred to a growth chamber $\left(25^{\circ} \mathrm{C}, 40\right.$ $\pm 10 \%$ relative humidity, and 12 -h photoperiod). In the case of the postinoculation treatments, plants were inoculated with conidial suspensions of $B$. sorokiniana or M. grisea and then incubated in the plastic container $\left(100 \%\right.$ relative humidity; $\left.25^{\circ} \mathrm{C}\right)$ for $24 \mathrm{~h}$ prior to silver treatments. The plants were treated with silver compounds as previously described and transferred to a growth chamber. Severity of leaf spot or gray leaf spot was measured as percent diseased areas of 10 randomly selected leaves per pot at 7 days after inoculation. The inoculation experiment was performed twice for each disease. Analysis of variance (ANOVA) was conducted to test the efficacy of silver preparations against the two diseases.

\section{RESULTS}

Inhibition of colony formation by silver. Silver compounds showed various

Table 2. Disease severity (\%) of leaf spot caused by Bipolaris sorokiniana and gray leaf spot caused by Magnaporthe grisea on perennial ryegrass treated with silver preparations and averaged across two experiments

\begin{tabular}{|c|c|c|c|c|}
\hline \multirow[b]{2}{*}{ Treatment [conc. ppm] } & \multicolumn{2}{|c|}{ B. sorokiniana } & \multicolumn{2}{|c|}{ M. grisea } \\
\hline & Pre-inoc ${ }^{a}$ & Post-inoc $^{b}$ & Pre-inoc & Post-inoc \\
\hline Water & 84.4 & 87.5 & 70.0 & 62.5 \\
\hline $\mathrm{AgNO}_{3}[50]$ & $0.6 * \mathrm{c}$ & 85.0 & $0.0 *$ & 52.5 \\
\hline $\mathrm{AgNO}_{3}[25]$ & $2.9^{*}$ & 88.8 & $0.3^{*}$ & 58.8 \\
\hline $\operatorname{Ag}(p)[200]^{d}$ & $6.9 *$ & 80.0 & $3.1 *$ & 53.8 \\
\hline $\operatorname{Ag}(\mathrm{p})[100]$ & $26.9 *$ & 91.3 & $5.1^{*}$ & 60.0 \\
\hline $\operatorname{Ag}(\mathrm{e})[50]^{\mathrm{e}}$ & $5.8 *$ & $62.5 *$ & $2.4 *$ & 53.1 \\
\hline $\operatorname{Ag}(e)[25]$ & $15.0 *$ & 87.5 & $4.1^{*}$ & 57.5 \\
\hline $\mathrm{AgNO}_{3}[50]+\mathrm{NaCl}^{\mathrm{f}}$ & $71.3 *$ & 90.0 & $39.4 *$ & 67.5 \\
\hline $\mathrm{AgNO}_{3}[25]+\mathrm{NaCl}$ & 77.5 & 91.9 & $43.8 *$ & 75.0 \\
\hline $\mathrm{Ag}(\mathrm{p})[200]+\mathrm{NaCl}$ & $18.1^{*}$ & $75.0 *$ & $5.8 *$ & 55.0 \\
\hline $\operatorname{Ag}(\mathrm{p})[100]+\mathrm{NaCl}$ & $20.0 *$ & 83.8 & $8.9 *$ & 54.4 \\
\hline $\mathrm{Ag}(\mathrm{e})[50]+\mathrm{NaCl}$ & $8.8 *$ & 80.0 & $16.4 *$ & 56.3 \\
\hline $\mathrm{Ag}(\mathrm{e})[25]+\mathrm{NaCl}$ & $32.3 *$ & 82.5 & $51.3 *$ & 55.0 \\
\hline $\mathrm{AgCl}[200]$ & 80.6 & 81.3 & $55.0 *$ & 61.3 \\
\hline $\mathrm{AgCl}[100]$ & 82.5 & 91.9 & 76.9 & 60.0 \\
\hline LSD at $P=0.01$ & 11.1 & 10.3 & 13.1 & 22.8 \\
\hline
\end{tabular}

a Silver preparations were sprayed on plants $3 \mathrm{~h}$ before inoculation of spores $\left(10^{5}\right.$ conidia $\left.\mathrm{ml}^{-1}\right)$.

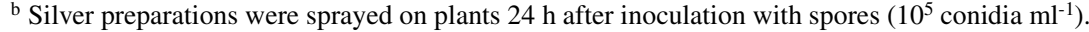

c Asterisks indicate significantly less disease compared with water control using Fisher's protected least significance differences at $P=0.01$.

d Nanoparticle silver, 20 to $30 \mathrm{~nm}$.

e Electrochemical silver generated by electrolysis.

${ }^{\mathrm{f}}$ Neutralized by adding $\mathrm{NaCl}$ to $\left[\mathrm{Ag}^{+}\right]=0$.

Table 1. Concentrations of silver preparations used for in vitro colony formation assay ${ }^{a}$

\begin{tabular}{|c|c|c|c|c|c|c|c|c|c|c|c|}
\hline \multirow{2}{*}{$\frac{\text { Treatment }}{\mathrm{AgNO}_{3}}$} & \multirow{2}{*}{$\frac{\mathbf{p H}}{5.8}$} & \multicolumn{5}{|c|}{ Conc. for Bipolaris sorokiniana (ppm) } & \multicolumn{5}{|c|}{ Conc. for Magnaporthe grisea (ppm) } \\
\hline & & 100 & 10 & 5 & 1 & 0.5 & 5 & 1 & 0.5 & 0.25 & 0.1 \\
\hline $\operatorname{Ag}(p)^{b}$ & 7.8 & 500 & 250 & 125 & 100 & & 200 & 100 & 50 & 25 & \\
\hline $\operatorname{Ag}(e)^{c}$ & 7.4 & 125 & 62.5 & 31.25 & 25 & & 50 & 25 & 12.5 & 6.25 & \\
\hline $\mathrm{AgCl}$ & 6.1 & 10,000 & & & & & 10,000 & & & & \\
\hline $\mathrm{AgNO}_{3}+\mathrm{NaCl}^{\mathrm{d}}$ & 6.2 & 100 & 10 & 5 & 1 & 0.5 & 5 & 1 & 0.5 & 0.25 & 0.1 \\
\hline $\mathrm{Ag}(\mathrm{p})+\mathrm{NaCl}$ & 8.3 & 500 & 250 & 125 & 100 & & 200 & 100 & 50 & 25 & \\
\hline $\mathrm{Ag}(\mathrm{e})+\mathrm{NaCl}$ & 7.4 & 125 & 62.5 & 31.25 & 25 & & 50 & 25 & 12.5 & 6.25 & \\
\hline
\end{tabular}

a Concentrations used in this study were determined in pilot experiments.

b Nanoparticle silver, 20 to $30 \mathrm{~nm}$.

c Electrochemical silver generated by electrolysis.

${ }^{\mathrm{d}}$ Neutralization by adding $\mathrm{NaCl}$ to obtain $\left[\mathrm{Ag}^{+}\right]=0$. 
levels of inhibition on colony formation of B. sorokiniana (Fig. 1) and M. grisea. As concentrations of the silver compounds increased, colony formation decreased. Antifungal activity of silver to reduce the colony formation was apparent within $1 \mathrm{~h}$. Extended exposure times of spores to $\mathrm{AgNO}_{3}$ (Figs. 2A and 3A), $\mathrm{Ag}(\mathrm{p}$ ) (Figs. 2B and $3 \mathrm{~B}$ ), and $\mathrm{Ag}(\mathrm{e})$ (Figs. $2 \mathrm{C}$ and $3 \mathrm{C}$ ) from $1 \mathrm{~h}$ up to $6 \mathrm{~h}$ did not significantly reduce colony formation $(P>0.05)$.

Since the measurement of colony formation did not differ significantly between two repeated experiments $(P>0.05)$, the data from the two independent experiments were averaged for each treatment and used to calculate $\mathrm{EC}_{50}$ (Table 3). The range of $\mathrm{EC}_{50}$ at 1 to $6 \mathrm{~h}$ after silver treatment on $B$. sorokiniana conidia was 1.2 to $2.2 \mathrm{ppm}$ of $\mathrm{AgNO}_{3}, 4.8$ to $8.8 \mathrm{ppm}$ of $\mathrm{Ag}(\mathrm{p})$, and 6.1 to $8.4 \mathrm{ppm}$ of $\mathrm{Ag}(\mathrm{e})$. The $\mathrm{EC}_{50}$ values for $M$. grisea were always numerically lower than those for B. sorokiniana, ranging 0.8 to $1.0 \mathrm{ppm}$ of $\mathrm{AgNO}_{3}, 3.9$ to $4.7 \mathrm{ppm}$ of $\operatorname{Ag}(\mathrm{p})$, and 5.6 to $6.8 \mathrm{ppm}$ of $\operatorname{Ag}(\mathrm{e})$ at 1 to $6 \mathrm{~h}$ after silver treatment.

The antifungal activity of $\mathrm{AgNO}_{3}$, $\operatorname{Ag}(\mathrm{p})$, and $\operatorname{Ag}(\mathrm{e})$ against $B$. sorokiniana was significantly diminished by chloride ions $(P<0.01)$. Silver cations of these silver preparations were neutralized with $\mathrm{NaCl}$ to produce $\mathrm{AgCl}$, which caused an increase in the average colony formation of B. sorokiniana by 20 to $30 \%$ compared with corresponding nonneutralized silver preparations (Fig. 2). In comparison to $B$. sorokiniana, $M$. grisea was more sensitive to the neutralized silver preparations, showing much lower $\mathrm{EC}_{50}$ values (Table $3)$. The antifungal activity of $\mathrm{Ag}(\mathrm{p})$ against $M$. grisea significantly diminished after neutralization by $\mathrm{NaCl}(P<0.01)$, but neutralized $\mathrm{AgNO}_{3}$ and $\mathrm{Ag}(\mathrm{e})$ still showed similar antifungal activities as corresponding nonneutralized silver solutions (Table 3 and Fig. 3).

$\mathrm{AgCl}$ at a relatively high concentration $(10,000 \mathrm{ppm})$ almost completely inhibited colony formation of both $B$. sorokiniana and $M$. grisea, and was also significantly influenced by chloride ions. An addition of $\mathrm{NaCl}$ to the $\mathrm{AgCl}$ preparation resulted in increased colony formation of $B$. sorokiniana up to $64.3 \%$ after $1 \mathrm{~h}$ exposure, $32.3 \%$ after $3 \mathrm{~h}$ exposure, and $10.8 \%$ after $6 \mathrm{~h}$ exposure. In the case of $M$. grisea, the $\mathrm{AgCl}$ preparation treated with $\mathrm{NaCl}$ increased colony formation up to $27.2 \%$ after $1 \mathrm{~h}$ exposure, $19.3 \%$ after $3 \mathrm{~h}$ exposure, and $16.1 \%$ after $6 \mathrm{~h}$ exposure.

Reduction of disease severity in plants by silver. Silver ions and nanoparticles effectively reduced leaf spot (Fig. 4) and gray leaf spot on perennial ryegrass without noticeable phytotoxicity, but $\mathrm{NaCl}$ significantly decreased their antifungal efficacy. The efficiency of silver in reducing the diseases significantly differed between $3 \mathrm{~h}$ before and $24 \mathrm{~h}$ after conidia inoculation $(P<0.01)$. Most silver preparations applied at $3 \mathrm{~h}$ before spore inoculation on the plants significantly reduced both diseases compared with the water control $(P<0.01)$. The preinoculation applications of $\mathrm{AgNO}_{3}$ (25 and $50 \mathrm{ppm}$ ), $\operatorname{Ag}(\mathrm{p})$ (200 ppm), and $\operatorname{Ag}(\mathrm{e})(50 \mathrm{ppm})$ were found to be the most effective, allowing less than $7 \%$ foliar damage by $\mathrm{B}$. sorokiniana and $M$. grisea under highly disease-conducive environmental conditions, which caused over $70 \%$ damage on watertreated control plants (Table 2). Some preinoculation treatments of neutralized $\mathrm{AgNO}_{3}, \mathrm{Ag}(\mathrm{p})$, and $\mathrm{Ag}(\mathrm{e})$ but not $\mathrm{AgCl}$ moderately reduced disease, but they still were less effective than nonneutralized silver preparations (Table 2). In contrast, delayed applications of silver preparations at $24 \mathrm{~h}$ after spore inoculation (postinoculation treatments) did not effectively reduce both diseases, causing $>50 \%$ foliar damage (Table 2).

\section{DISCUSSION}

Management of fungal diseases on food crops and ornamental plants is economically important. Recently, more efforts have been given to develop safe management methods that pose less danger to humans and animals, and have focused on overcoming deficiencies of synthetic fungicides. The current investigation showed that silver ions and nanoparticles with low toxicity and a broad spectrum of antimicrobial activity were also very effective for reducing plant diseases caused by sporeproducing phytopathogenic fungi. However, the extrapolation of these findings to more general cases is limited due to the fact that this current study is based on in vitro petri dish and in planta growth chamber evaluations. Still, this research provides valuable preliminary efficacy data of silver compounds for control of plant diseases.

There have been numerous reports of the antimicrobial activity of silver. How-

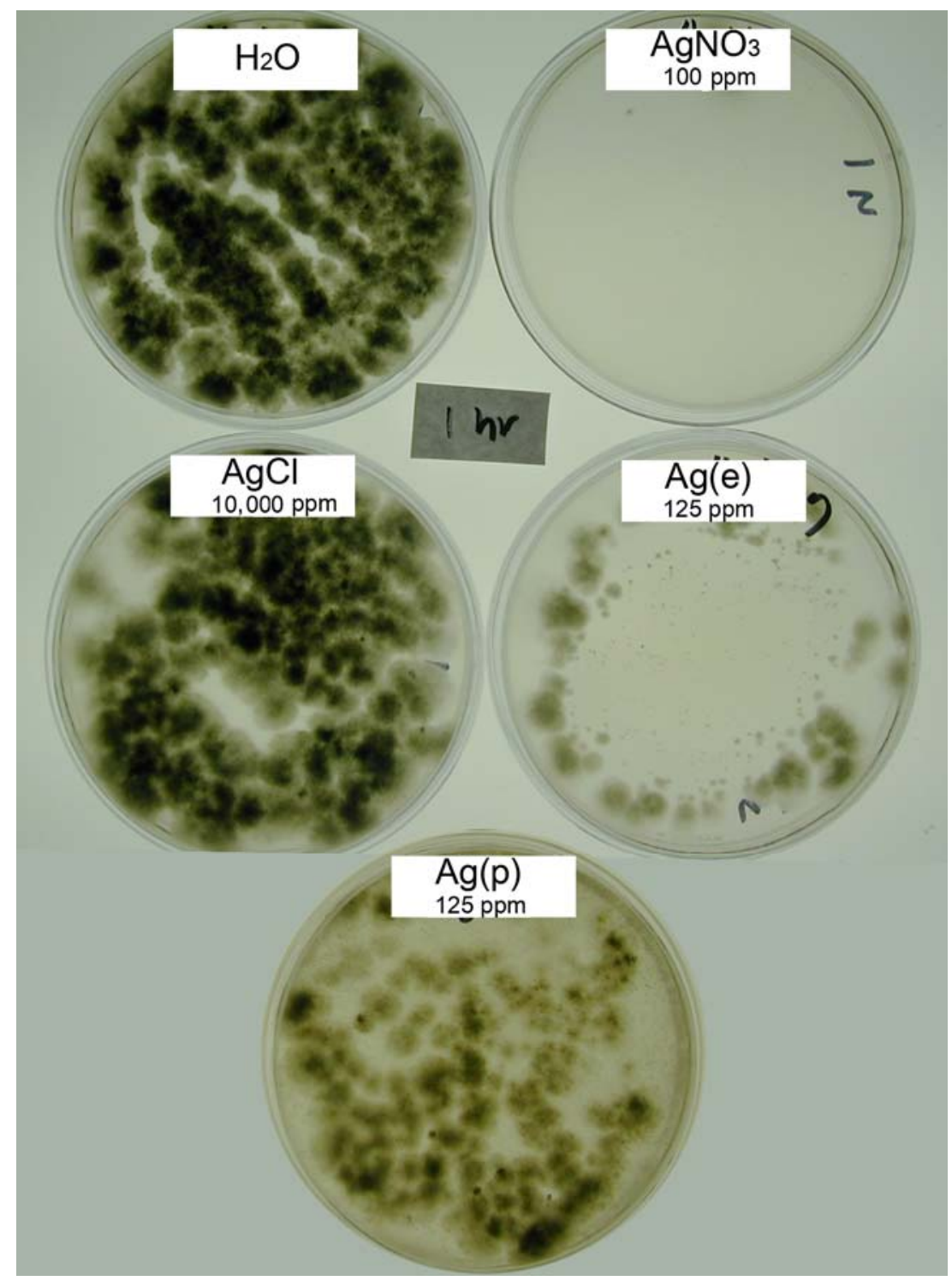

Fig. 1. Colony formation of Bipolaris sorokiniana on potato dextrose agar medium, $1 \mathrm{~h}$ post-treatment of spores with water, $\mathrm{AgNO}_{3}, \mathrm{AgCl}$, silver nanoparticles $[\mathrm{Ag}(\mathrm{p})]$ and electrochemical silver $[\mathrm{Ag}(\mathrm{e})]$. Images were captured after culture plates had been incubated for 6 days at $25^{\circ} \mathrm{C}$. 
ever, antifungal properties of different forms of silver often coexisting in solution have not been investigated fully. Furthermore, there have been few studies conducted for testing antifungal activity of silver for plant-pathogenic fungi. Results presented in this study confirm that silver ions and nanoparticles have significant inhibitory effects on colony formation from conidia of $B$. sorokiniana and $M$. grisea. The sensitivities of the two fungal species to silver compounds were different. Conidia of $B$. sorokiniana, with bigger size (median length more than $60 \mu \mathrm{m}$ ) and darker color, showed higher tolerance to silver than those of $M$. grisea (17 to 28 $\mu \mathrm{m})$. This is consistent with previous reports that stated antimicrobial activity of silver was different depending on microbial species $(7,25,27)$. The colony formation from conidia of both plant-pathogenic fungi was influenced in the range of $\mathrm{EC}_{50}$ values of 0.9 to $2.2 \mathrm{ppm}$ of $\mathrm{AgNO}_{3}, 3.9$ to $8.8 \mathrm{ppm}$ of $\operatorname{Ag}(\mathrm{p})$, and 5.6 to $8.4 \mathrm{ppm}$ of $\operatorname{Ag}(\mathrm{e})$. This
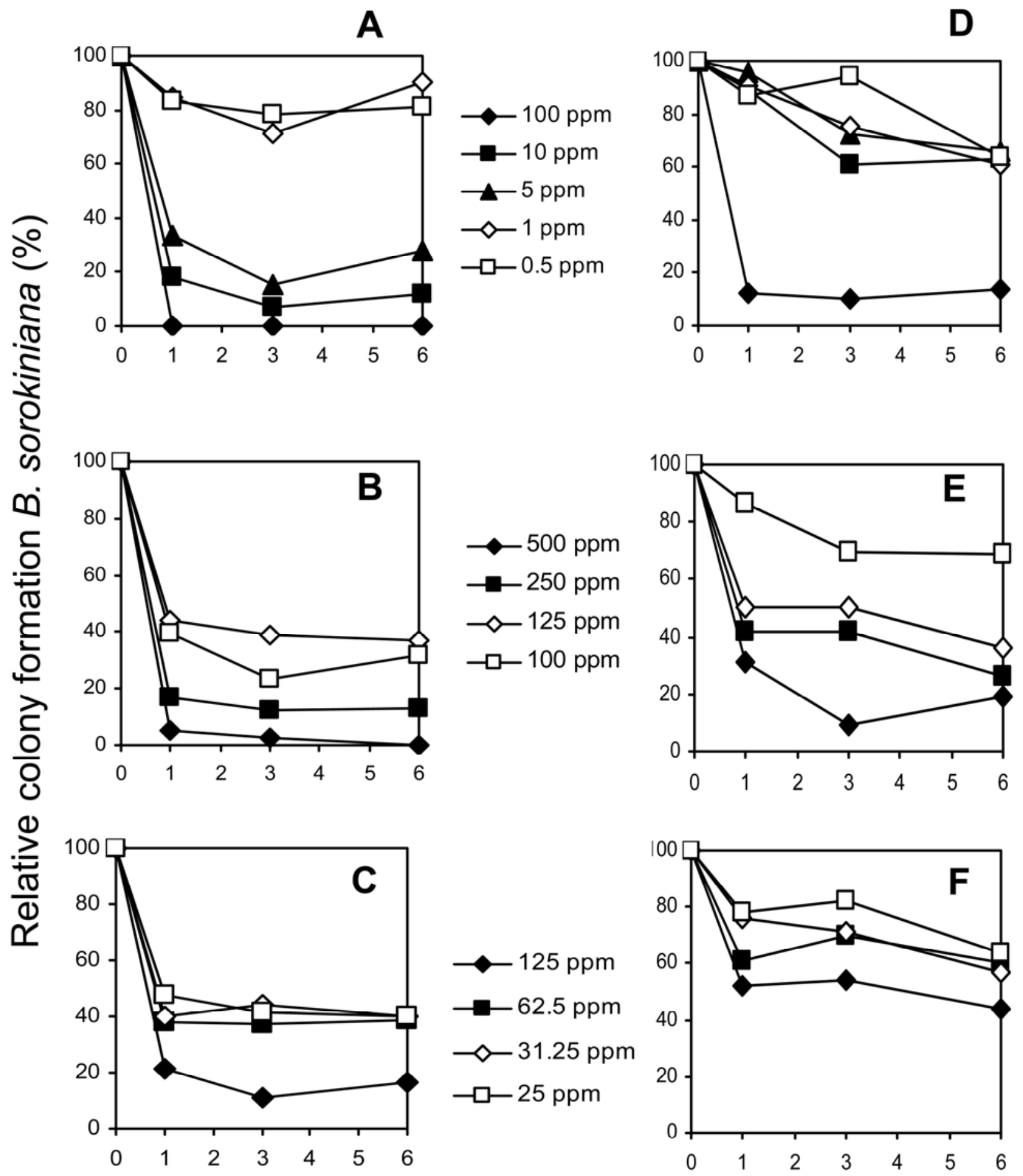

Time of incubation prior to plating (hours)

Fig. 2. Colony formation of Bipolaris sorokiniana affected by $\mathbf{A}, \mathrm{AgNO}_{3}, \mathbf{B}$, silver nanoparticles $[\mathrm{Ag}(\mathrm{p})]$, C, electrochemical silver $[\mathrm{Ag}(\mathrm{e})]$, D, neutralized $\mathrm{AgNO}_{3}, \mathbf{E}$, neutralized $\mathrm{Ag}(\mathrm{p})$, and $\mathbf{F}$, neutralized $\mathrm{Ag}(\mathrm{e})$ after silver cations were removed by $\mathrm{NaCl}$. 
range of silver doses is 1 to 8 times higher than the maximal concentration of silver (1.142 ppm) allowed in drinking water for human consumption for short-term exposure (1 to 10 days) by the U.S. EPA (1).

This study was the first to demonstrate that ionic forms of silver have strong antifungal activity against $B$. sorokiniana and $M$. grisea, while their antibacterial effects have been previously well described $(18,20,25)$. The silver ionic forms of $\mathrm{AgNO}_{3}$ caused a significant reduction of colony formation within $1 \mathrm{~h}$ at low concen- trations $\left(\mathrm{EC}_{50}\right.$ for B. sorokiniana $=2.2$ $\mathrm{ppm}$ and $\mathrm{EC}_{50}$ for $M$. grisea $=0.9 \mathrm{ppm}$ ). Another piece of direct evidence of the importance of silver ions for antifungal activity is that silver compounds are significantly influenced by $\mathrm{NaCl}$. After silver cations of $\mathrm{AgNO}_{3}$ reacted with chloride ions and formed the insoluble precipitate $\mathrm{AgCl}, \mathrm{AgNO}_{3}$ showed a dramatic reduction in antifungal activity and yielded higher $\mathrm{EC}_{50}$ values than nonneutralized $\mathrm{AgNO}_{3}$ (Table 3). $\mathrm{AgCl}$ has also been known to have antimicrobial activity (25) but was much less effective than silver ions for inhibiting colony formation and suppressing disease development by $B$. sorokiniana and $M$. grisea.

Silver nanoparticles showed significant antifungal activity in both in vitro petri dish assays and in planta inoculation experiments. Silver nanoparticles may directly attach to and penetrate the cell membrane to kill spores, although penetration of silver nanoparticles into microbial cell membranes is not completely understood (18). There was a significant reduc-

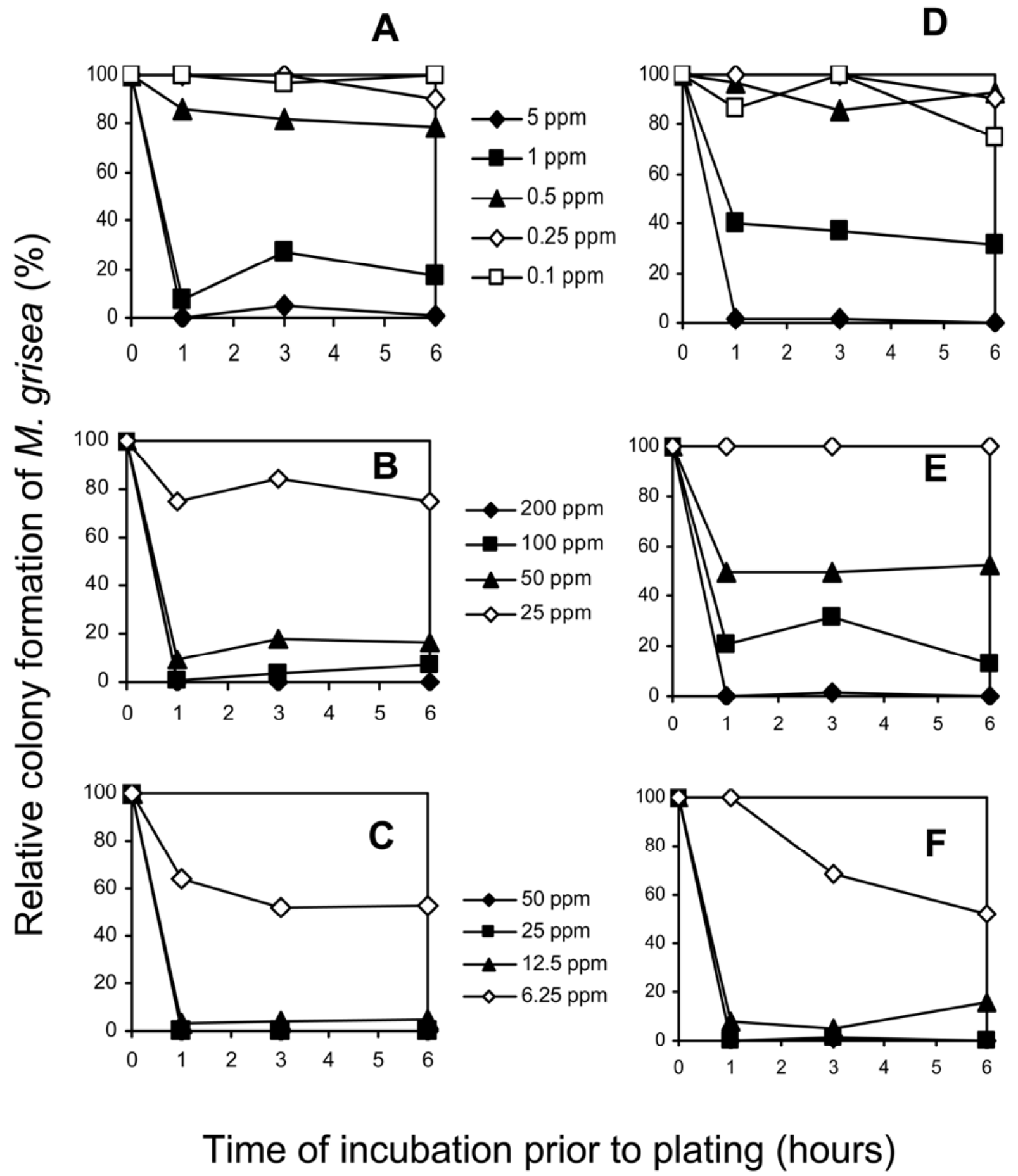

Fig. 3. Colony formation of Magnaporthe grisea affected by $\mathbf{A}, \mathrm{AgNO}_{3}$, $\mathbf{B}$, silver nanoparticles [Ag(p)], $\mathbf{C}$, electrochemical silver [Ag(e)], D, neutralized $\mathrm{AgNO}_{3}, \mathbf{E}$, neutralized $\mathrm{Ag}(\mathrm{p})$, and $\mathbf{F}$, neutralized $\mathrm{Ag}(\mathrm{e})$ after silver cations were removed by $\mathrm{NaCl}$. 
tion of antifungal activity of $\operatorname{Ag}(p)$ after neutralization of silver cations with $\mathrm{NaCl}$ (Figs. 2B and E, and $3 \mathrm{~B}$ and $\mathrm{E}$ ). The reduction of antifungal activity results from limiting the concentration of silver cations in solution by producing $\mathrm{AgCl}$, a less effective form of silver. Similarly, the antifungal activity of $\mathrm{Ag}(\mathrm{e})$ generated by electrolysis was significantly reduced after neutralization by $\mathrm{NaCl}$, indicating that its primary antifungal property is attributable to silver ions (Figs. 2C and F, and 3C and F). In addition to ions, nano-sized particles in $\operatorname{Ag}(\mathrm{e})$ are likely to be involved in affecting spores, which might account for the remaining antifungal property of $\mathrm{Ag}(\mathrm{e})$.

The preventative application of the silver preparations more effectively reduced disease severity on plants than the postinoculation application. A mechanism of this antifungal activity is suggested by the germination and infection process in these fungi. Both $B$. sorokiniana and $M$. grisea cause foliar diseases and reproduce as asexual conidia. Disease infection is initiated by the attachment of spores to the

Table 3. Effective concentration of silver preparations to cause a $50 \%$ reduction in colony formation $\left(\mathrm{EC}_{50}\right)$ for Bipolaris sorokiniana and Magnaporthe grisea

\begin{tabular}{lcccccccc}
\hline & \multicolumn{3}{c}{$B$. sorokiniana $(\mathbf{p p m})$} & & \multicolumn{3}{c}{ M. grisea $(\mathbf{p p m})$} \\
\cline { 2 - 3 } \cline { 8 - 9 } Treatment & 1 HAI $^{\mathbf{a}}$ & 3 HAI & 6 HAI & & 1 HAI & 3 HAI & 6 HAI \\
\hline $\mathrm{AgNO}_{3}$ & 2.2 & 1.2 & 2.0 & & 0.9 & 1.0 & 0.8 \\
$\mathrm{Ag}(\mathrm{p})^{\mathrm{b}}$ & 8.8 & 4.8 & 5.4 & & 3.9 & 4.7 & 4.0 \\
$\mathrm{Ag}\left(\mathrm{e}^{\mathrm{c}}\right.$ & 8.4 & 6.1 & 6.1 & & 6.8 & 5.7 & 5.6 \\
$\mathrm{AgNO}_{3}+\mathrm{NaCl}^{\mathrm{d}}$ & 92.9 & 13.6 & 6.9 & & 1.2 & 1.1 & 1.1 \\
$\mathrm{Ag}(\mathrm{p})+\mathrm{NaCl}$ & 216.8 & 160.5 & 121.4 & & 60.7 & 64.4 & 59.2 \\
$\mathrm{Ag}(\mathrm{e})+\mathrm{NaCl}$ & 134.9 & 182.7 & 92.3 & & 10.3 & 7.4 & 6.1 \\
\hline
\end{tabular}

${ }^{\mathrm{a}}$ Hour after incubation prior to plating.

${ }^{\mathrm{b}}$ Nanoparticle silver, 20 to $30 \mathrm{~nm}$.

${ }^{\mathrm{c}}$ Electrochemical silver generated by electrolysis.

${ }^{\mathrm{d}}$ Neutralization by adding $\mathrm{NaCl}$ to obtain $\left[\mathrm{Ag}^{+}\right]=0$.

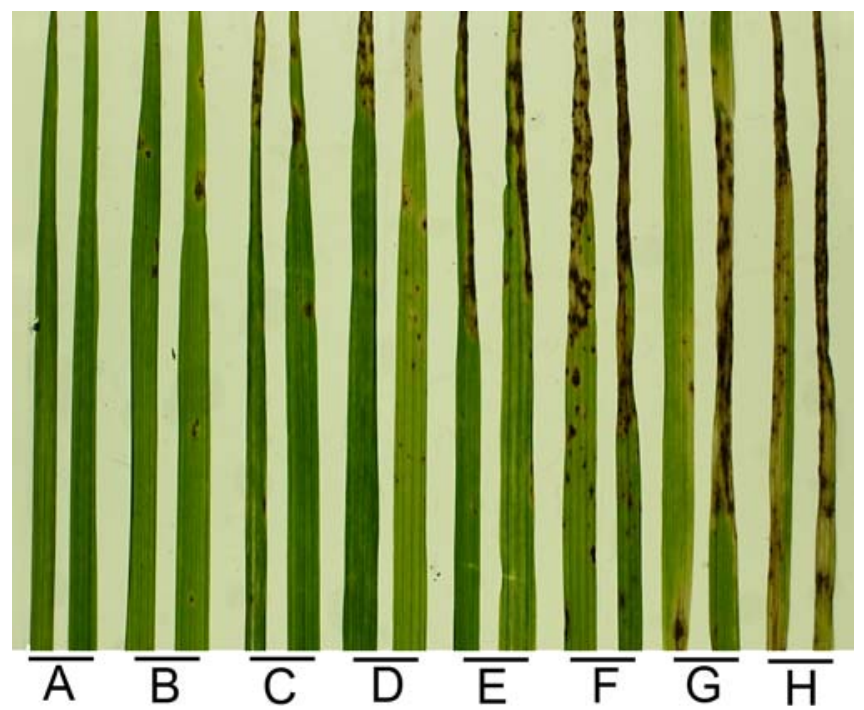

Fig. 4. Disease symptoms on leaves of perennial ryegrass 7 days postinoculation with Bipolaris sorokiniana. Three hours before conidia inoculation, the plants were treated with $\mathbf{A}$, electrochemical silver [Ag(e), $50 \mathrm{ppm}], \mathbf{B}$, silver nanoparticles [Ag(p), $200 \mathrm{ppm}], \mathbf{C}, \mathrm{AgNO}_{3}(50 \mathrm{ppm}), \mathbf{D}$, neutralized $\mathrm{Ag}(\mathrm{e})(50 \mathrm{ppm}+\mathrm{NaCl}), \mathbf{E}$, neutralized $\mathrm{Ag}(\mathrm{p})(200 \mathrm{ppm}+\mathrm{NaCl}), \mathbf{F}$, neutralized $\mathrm{AgNO}_{3}(50 \mathrm{ppm}+$ $\mathrm{NaCl})$ after silver cations were removed by $\mathrm{NaCl}, \mathbf{G}, \mathrm{AgCl}(200 \mathrm{ppm})$, and $\mathbf{H}$, water. nanoparticles work better before spores penetrate and colonize within the plant tissue. Our follow-up research focuses on extended applicability of silver for control of $B$. sorokiniana and $M$. grisea in the field, and evaluation of the efficacy of silver on different types of pathogens such as soilborne sterile fungi that rarely produce spores. Further research should focus on the development of silver compounds, compositions, and carriers than have improved stability against chloride ions. At the same time, the environmental tracking of silver when applied in the field is important to assess the impact on environmental and human health. This information is imperative for future registration and labeling of the silver nanoparticles as fungicides for crop protection.

\section{ACKNOWLEDGMENTS}

We gratefully acknowledge Jiyeon Ban and Eddi Kim for their help in running in vitro assays. We also thank Nick Beaulieu and Jay Popko for comments on the manuscript.

\section{LITERATURE CITED}

1. Anonymous. 1990. Toxicological profile for silver. U.S. Department of Health and Human Services and Public Health Service, Atlanta, GA.

2. Berger, T. J., Spadaro, J. A., Chapin, S. E., and Becker, R. O. 1976. Electrically generated silver ions: Quantitative effects on bacterial and mammalian cells. Antimicrob. Agents Chemother. 9:357-358.

3. Bianchini, A., Grosell, M., Gregory, S. M., and Wood, C. M. 2002. Acute silver toxicity in aquatic animals is a function of sodium uptake rate. Environ. Sci. Technol. 36:1763-1766.

4. Clement, J. L., and Jarret, P. S. 1994. Antimicrobial silver. Metal-Based Drugs 1:467-482.

5. Conrad, A. H., Tramp, C. R., Long, C. J., Wells, D. C., Paulsen, A. Q., and Conrad, G. W. $1999 . \mathrm{Ag}^{+}$alters cell growth, neurite extension, cardiomyocyte beating, and fertilized egg constriction. Aviat. Space Environ. Med. 70:1096-1105.

6. Dowsett, C. 2004. The use of silver-based dressings in wound care. Nurs. Stand. 19:5660.

7. Galeano, B., Korff, E., and Nicholson, W. L. 2003. Inactivation of vegetative cells, but not spores, of Bacillus anthracis, B. cereus, and B. subtilis on stainless steel surfaces coated with an antimicrobial silver- and zinc-containing zeolite formulation. Appl. Environ. Microbiol. 69:4329-4331.

8. Hirasawa, F., Kawarada, Y., Sato, M., Suzuki, S., Terada, K., Miura, N., Fujii, M., Kato, K., Takizawa, Y., and Sugiyama, T. 1997. The effect of silver administration on the biosynthesis and the molecular properties of rat ceruloplasmin. Biochim. Biophys. Acta 1336:195201.

9. Holden, W. S. 1970. Water Treatment and Examination. Churchill Livingstone, Ltd., Edinburgh.

10. Hotta, M., Nakajima, H., Yamamoto, K., and Aono, M. 1998. Antibacterial temporary filling materials: The effect of adding various ratios of Ag-Zn-Zeolite. J. Oral Rehabil. 25:485-489.

11. Howard, R., and Ferrari, M. 1989. Role of melanin in appressorium function. Exp. Mycol. 13:403-418.

12. Jung, W. K., Kim, S. H., Koo, H. C., Shin, S., Kim, J. M., Park, Y. K., Hwang, S. Y., Yang, H., and Park, Y. H. 2007. Antifungal activity of the silver ion against contaminated fabric. Mycoses 50:265-269. 
13. Lin, Y. S., Vidic, R. D., Stout, J. E., and Yu, V. L. 2002. Negative effect of high $\mathrm{pH}$ on biocidal efficacy of copper and silver ions in controlling Legionella pneumophila. Appl. Environ. Microbiol. 68:2711-2715.

14. Liu, Z., Stout, J. E., Tedesco, L., Boldin, M., Hwang, C., Diven, W. F., and Yu, V. L. 1994. Controlled evaluation of copper-silver ionization in eradicating Legionella pneumophila from a hospital water distribution system. J. Infect. Dis. 169:919-922.

15. Matsuura, T., Abe, Y, Sato, Y, Okamoto, K. Ueshige, M., and Akagawa, Y. 1997. Prolonged antimicrobial effect of tissue conditioners containing silver-zeolite. J. Dent. 25:373-377.

16. McDonnell, G., and Russell, A. D. 1999. Antiseptics and disinfectants: Activity, action, and resistance. Clin. Microbiol. Rev. 12:147-179.

17. Morgan, T. P., Guadagnolo, C. M., Grosell, M., and Wood, C. M. 2005. Effects of water hardness on toxicological responses to chronic waterborne silver exposure in early life stages of rainbow trout (Oncorhynchus mykiss). Environ. Toxicol. Chem. 24:1642-1647.

18. Morones, J. R., Elechiguerra, J. L., Camacho, A., Holt, K., Kouri, J. B., Ramírez, J. T., and Yacaman, M. J. 2005. The bactericidal effect of silver nanoparticles. Nanotechnology 16:2346-2353.

19. Oloffs, A., Grosse-Siestrup, C., Bisson, S., Rinck, M., Rudolph, R., and Gross, U. 1994. Biocompatibility of silver-coated polyurethane catheters and silver-coated Dacron ${ }^{\circledR}$ material. Biomaterials 15:753-758.

20. Pal, S., Tak, Y. K., and Song, J. M. 2007. Does the antibacterial activity of silver nanoparticles depend on the shape of the nanoparticle? A study of the Gram-negative bacterium Escherichia coli. Appl. Environ. Microbiol. 73:1712-1720.

21. Park, H.-J., Kim, S. H., Kim, H. J., and Choi, S.-H. 2006. A new composition of nanosized silica-silver for control of various plant diseases. Plant Pathol. J. 22:295-302.

22. Raad, I. I., and Hanna, H. A. 2002. Intravascular catheter-related infections: New horizons and recent advances. Arch. Intern. Med. 162:871-878.

23. Reddish, G. 1954. Antiseptics, Disinfectants, Fungicides, and Chemical and Physical Sterilization. Lea \& Febiger, Philadelphia.

24. Russell, A. D., and Hugo, W. B. 1994. Antimicrobial activity and action of silver. Prog. Med. Chem. 31:351-370.
25. Simonetti, N., Simonetti, G., Bougnol, F., and Scalzo, M. 1992. Electrochemical $\mathrm{Ag}^{+}$for preservative use. Appl. Environ. Microbiol. 58:3834-3836.

26. Sondi, I., and Salopek-Sondi, B. 2004. Silver nanoparticles as antimicrobial agent: A case study on E. coli as a model for Gram-negative bacteria. J. Colloid Interface Sci. 275:177-182.

27. Takai, K., Ohtsuka, T., Senda, Y., Nakao, M. Yamamoto, K., Matsuoka, J., and Hirai, Y. 2002. Antibacterial properties of antimicrobialfinished textile products. Microbiol. Immunol. 46:75-81.

28. Tokumaru, T., Shimizu, Y., and Fox, C. L., Jr. 1974. Antiviral activities of silver sulfadiazine in ocular infection. Res. Commun. Chem. Pathol. Pharmacol. 8:151-158.

29. Tucker, S. L., and Talbot, N. J. 2001. Surface attachment and pre-penetration stage development by plant pathogenic fungi. Annu. Rev. Phytopathol. 39:385-417.

30. Yamanaka, M., Hara, K., and Kudo, J. 2005 Bactericidal actions of a silver ion solution on Escherichia coli, studied by energy-filtering transmission electron microscopy and proteomic analysis. Appl. Environ. Microbiol. 71:7589-7593. 